\title{
Detection of HSV1 DNA by in situ hybridisation in human brain after immunosuppression
}

\author{
JOHN SALDANHA, ${ }^{*} \ddagger$ RICHARD NP SUTTON,* ALISON GANNICLIFFE, \\ BRIAN FARRAGHER, $\dagger$ RUTH F ITZHAKI*
}

From the Departments of Virology* and Medical Statistics, $\uparrow$ University Hospital of South Manchester, Withington Hospital, Manchester, UK

SUMMARY Human brain cells were examined for the presence of herpes simplex virus type 1 (HSV1) DNA sequences by in situ hybridisation. Viral genome was detected in immunosuppressed patients with virological evidence of past HSV infection but not in immunosuppressed patients with no such evidence. In patients who had not been immunosuppressed, no HSV DNA sequences were detectable.

Over fifty years ago, a model for recurrent herpetic disease proposed that latent infection occurs in sensory ganglia. ${ }^{1}$ More recently, co-cultivation studies have suggested that latent virus is present both in brain and ganglia. Subsequently, preliminary studies in this laboratory ${ }^{2}$ showed, by molecular hybridisation to DNA from brain, that herpes simplex virus type 1 (HSV1) DNA sequences were detectable in patients with chronic but not acute psychiatric disease and also in mice six months after infection with HSV1. Since then, various hybridisation studies have confirmed the presence of HSV1 sequences in brains of humans ${ }^{3}$ and of mice after experimental infection. ${ }^{45}$

It is not known whether latent herpes virus affects host cell metabolism in a manner comparable to certain persistent viruses, such as lymphocytic choriomeningitis virus, ${ }^{6}$ which can turn off the differentiation function of a cell without killing it, or even whether there is any transcription of the latent herpes genome. ${ }^{7-9}$ Possibly the latter is dormant and damage to the host cell occurs only when the virus is reactivated following immunosuppression or other stress. Experimental immunosuppression in mice bearing latent HSV1 infection leads to reactivation of virus in brain and to transient neurological signs. ${ }^{10}$ In man, such effects cannot be determined experimentally but in illnesses such as acute leukaemia, both disease and cytotoxic treatment involve immunosuppression.

tPresent address: Department of Physiology, Royal Free Hospital School of Medicine, Rowland Hill Street, London NW3 2PF, UK.

Present address and address for reprint requests: Dr Ruth F Itzhaki, Molecular Neurobiology Laboratory, Department of Ophthalmic Optics, UMIST, PO Box 88, Manchester M60 1QD, UK.

Received 30 May 1985 and in final revised form 24 October 1985. Accepted 2 November 1985
Using in situ hybridisation, we have examined specimens of brain (obtained post-mortem) from such patients, on all of whom, in life, standard diagnostic virological investigations had been made. Thus we have been able to answer the questions: is HSV DNA detectable in brains from patients who had previously been infected with HSV and who were subsequently immunosuppressed?; is it detectable in those patients not infected but immunosuppressed, or infected but not immunosuppressed?

From our studies, the detectability of HSV1 DNA in brain has been linked with evidence of previous infection and with immunosuppression.

\section{Patients and methods}

\section{Patients}

Two groups were examined. In one (A), virological studies in life had been carried out. It included seven patients with acute myelocytic or lymphoblastic leukaemia. All of these were immunocompromised; two had received total body irradiation as part of a bone-marrow transplant procedure. In another patient of group A, the clinical presentation and post-mortem histological findings led to a firm diagnosis of HSV encephalitis; infectious virus was recovered from a throat swab taken shortly before death but no virus was recovered from post-mortem brain specimens. In the second group (B), no studies in life had been possible. These patients had not been immunocompromised, their diagnoses being diverse and unrelated to neurological or psychiatric disease. Although no data on past HSV1 infections were available for these patients, it can be assumed that the majority had suffered a past infection $(80 \%-90 \%$ of humans have detectable antibodies to HSV1 ${ }^{11}$ ). These patients can therefore be regarded as "controls" for the immunosuppressed patients.

\section{LABORATORY METHODS}

Virological investigation

Virus isolation Swabs were taken into virus transport 
medium and subsequently inoculated into MRC5 human fibroblast and BK tissue cultures: viruses were identified by neutralisation tests.

Electron microscopy (EM) Material from lesions was placed on microscope slides and air-dried. The material was later re-suspended in distilled water and a drop placed on a formvar-carbon-coated EM grid. The sample was then stained with $3 \%$ phosphotungstic acid (pH 6.5) and examined under the electron microscope (AEI, EM1801 or ME6B). Photographs were taken of all positive samples. Serology With slight modifications, the classical technique $^{12}$ of complement fixation as applied to the diagnosis of virus diseases was followed. Tests were carried out in plastic microtitre plates. About three $50 \%$ haemolytic doses (HD50) of complement were used and in the titration of this, any slight anti-complementariness of the standard Public Health Laboratory Serivice antigens employed was taken into account. The primary reaction took place at $4^{\circ} \mathrm{C}$ overnight. Sensitised red cells were added and the secondary reaction allowed to proceed for one hour at $37^{\circ} \mathrm{C}$. Endpoints were read by interpolation and sera with titres of less than 10 were regarded as negative.

\section{DNA-DNA HYBRIDISATION STUDIES}

Preparation of viral DNA, Vero and HeLa DNA HSV1 nucleocapsids were isolated and purified from Vero cells infected with HSV1 at a low multiplicity of infection. ${ }^{13}$ DNA was extracted by lysing nucleocapsids in $2 \%(w / v)$ sodium dodecyl sulphate (SDS) at $60^{\circ} \mathrm{C}$ for 30 minutes and purified by phenol-chloroform extraction and $\mathrm{CsCl}$ gradient ultracentrifugation. $\left[{ }^{3} \mathrm{H}\right]$-labelled $\mathrm{HSV} 1$ and $\lambda$ DNA probes and $\left[{ }^{32} \mathrm{P}\right]$-labelled HSV1 DNA were prepared by nick-translation. ${ }^{14}$ Vero and HeLa DNA were prepared by a method using hot SDS which we devised for extracting DNA from human brain. ${ }^{15}$

Hybridisation In situ hybridisation was carried out by a modification of the method of MacGregor and Varley. ${ }^{16}$ The cells were fixed in ethanol-acetic (3:1), pipetted on to gelatine-coated slides and fixed at room temperature. Following two washes in $2 \times$ SSC (SSC is $0.15 \mathrm{M} \mathrm{NaCl}$, $0.015 \mathrm{M}$ trisodium citrate, $\mathrm{pH} 7.0$ ), the cells were denatured in $0.1 \mathrm{~N} \mathrm{NaOH}$ at $20^{\circ} \mathrm{C}$ for 3 minutes and dehydrated in ethanol. $\left[{ }^{3} \mathrm{H}\right]-H S V 1$ DNA probe (specific activity $1-2 \times$ $10^{7} \mathrm{cpm} / \mu \mathrm{g}$ ) was denatured in $0.1 \mathrm{~N} \mathrm{NaOH}, 50 \%$ formamide and $4 \times \mathrm{SSC}$ at $0^{\circ} \mathrm{C}$ for 3 minutes. The $\mathrm{pH}$ of the mixture was then adjusted to neutrality with $0 \cdot 1 \mathrm{~N} \mathrm{HCl}$ and heatdenatured, sonicated calf thymus DNA and dextran sulphate were added to final concentrations of $100 \mu \mathrm{g} / \mathrm{ml}$ and $10 \%$ respectively. Approximately $1 \times 10^{5} \mathrm{cpm}$ of probe in $30 \mu \mathrm{l}$ was allowed to hybridise to each slide for 16 hours at $37^{\circ} \mathrm{C}$. Slides were rinsed in $2 \times$ SSC, $0 \cdot 1 \%$ SDS, followed by washing in 3 changes of $2 \times \mathrm{SSC}$ at $65^{\circ} \mathrm{C}$ for 1 hour, one wash in $2 \times$ SSC, $0.1 \%$ SDS at room temperature for 10 minutes, one wash in $2 \times \mathrm{SSC}$ at room temperature for 10 minutes, one wash in $5 \%(\mathrm{w} / \mathrm{v})$ trichloroacetic acid at $4^{\circ} \mathrm{C}$ for 5 minutes and 30 minutes washing in three changes of 2 $\times$ SSC at room temperature. After dehydration in ethanol, slides were coated with Ilford $\mathrm{K} 5$ emulsion diluted with an equal volume of distilled water, exposed at $4^{\circ} \mathrm{C}$ for 14 days, developed, and stained with Giemsa.

Controls for hybridisation methods

(1) Purity of probe It was essential to ensure that our viral

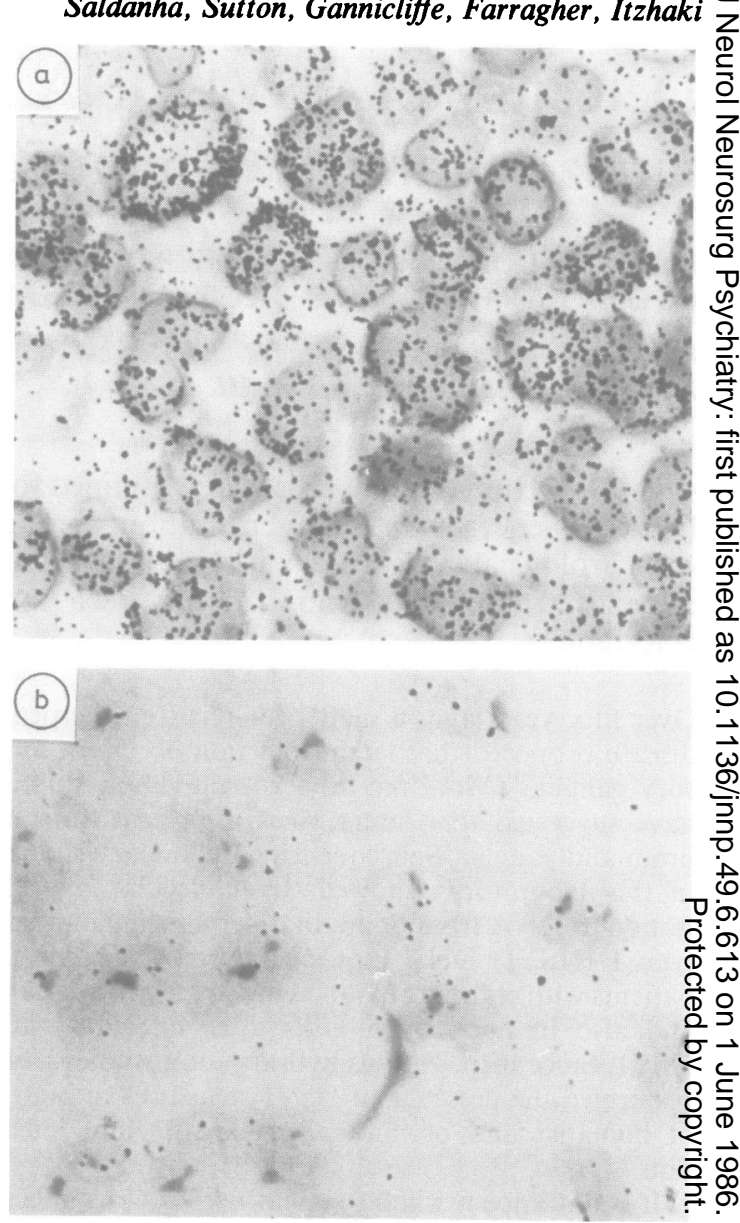

Fig 1 In situ hybridisation of ${ }^{3} \mathrm{H}$ - $-\mathrm{HSVI}$ DNA to (a) $H S V$-1-infected Vero cells and (b) uninfected Vero cells. $(\times 1000$. $)$

DNA isolated from Vero cells was free of cellular DNA contamination. We found that the $\mathrm{Tm}$ (the melting temperature of duplex DNA which decreases with increase in mismatched base-pairs) of the DNA in $0.1 \times$ SSC was $82.5^{\circ} \mathrm{C}$; this corresponds to $65.5 \%(\mathrm{G}+\mathrm{C})$ (guanine + cytosine) base-pairs, characteristic of HSV1 DNA. To check the absence of appreciable contamination with cellular DNA, dot blot hybridisation ${ }^{17}$ was used to compare the blackening produced by a dot of Vero cell DNA with that of a series of HeLa cell DNA samples containing different amounts of added HSVI DNA, after hybridisation to $\left[{ }^{32} \mathrm{P}\right.$-labelled HSV1 DNA. This showed the contamination level to be equivalent to only $0.01-0.05$ viral genomes per cell genome, that is, far too low to produce any false positives on hybridisation.

(2) Positive hybridisation control The specificity of the HSV1 probe was checked by incubation with Vero cells 48 hours after infection with HSV1 (multiplicity of infection $N$ 1-2 plaque-forming units per cell). The majority of cells showed a cytopathic effect and this was consistent with 


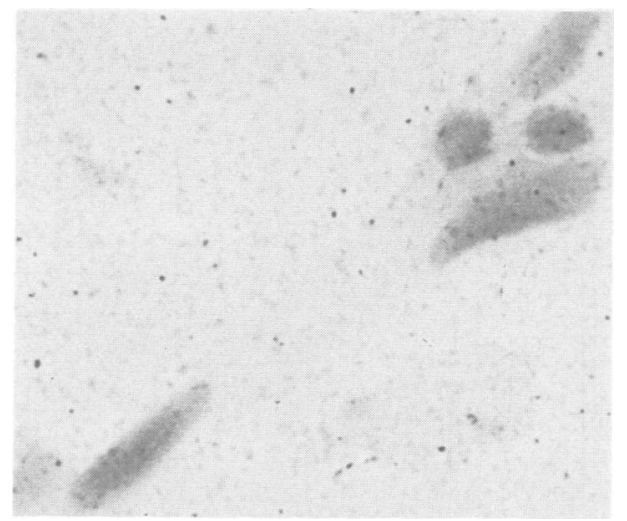

Fig 2 In situ hybridisation of $\left[{ }^{3} H\right]-\lambda$ DNA to human brain nuclei (patient $\mathrm{mg}) .(\times 1000$.)

heavy labelling (fig la), whereas tests with uninfected Vero cells were negative (fig lb), no cell having more than seven grains.

(3) Negative hybridisation controls No grains in excess of the background level were found when $\lambda$ DNA was used as probe (fig 2), or when brain samples found to be strongly positive when examined by our normal procedure were tested without prior denaturation, or when slides were treated with DNAase after hybridisation. This indicates that the grains detected in our test specimens resulted specifically from hybridisation of $\left[{ }^{3} \mathrm{H}\right]$-labelled HSV1 probe to complementary HSV1 DNA sequences within the brain cells.

(4) The avoidance of observer bias Clinical and virological results were not disclosed until the hybridisation studies had been completed.

\section{Quantitation of in situ hybridisation and its statistical} analysis

Grains were counted in nuclei only as, in the case of neurons, the cytoplasm was usually poorly defined. At least two separate experiments were carried out on each sample; in each of these, grains were counted in about 200 nuclei from at least 10 random fields (that is, over 400 nuclei were examined from each sample). For measurement of background levels, we counted the grains present in areas adjacent to or equivalent to those of the cells; values of $0-5$ grains per area were obtained (mean of 3 ).

We examined the distribution of grain counts in cells from each brain specimen by means of cumulative frequency curves. These show the percentage of grain counts (per cell) greater than (or less than) any selected grain count level. Appropriate percentiles can be obtained from the curves by inspection.

\section{Results}

\section{Virological investigations}

Virological investigations were carried out on the leukaemic patients over many months prior to their deaths and many specimens were tested (table 1). The HSV antibody levels are within our normal range for healthy adults. The short-term standard treatment regimes with cytotoxic drugs result in considerable suppression of cellular immunity but, to a much lesser degree, in impairment of humoral immunity; immunoglobulin and antibody levels remain normal, although the humoral response to a new antigenic challenge is reduced. ${ }^{18}$

In four patients, all with antibody, HSV was recovered in tissue culture, or identified by electron microscopy, or both, in specimens taken from peripheral sites (almost invariably oropharynx). This recovery of virus confirms unequivocably that these patients $(\mathrm{hb}$, ab, mg, wf) had a latent HSV infection which was capable of reactivation. In two patients $(\mathrm{mf}, \mathrm{pj})$ there was serological evidence of past HSV infection but no reactivation of virus was observed. In no instance was virus detected in post-mortem brain tissue by inoculation of tissue culture or by electron microscopy (results not shown in table 1). In patients $\mathrm{mb}$ and ps there was no virological evidence of previous HSV infection. In three other patients (tw, gh, ts), antemortem virological studies could not be performed but it is reasonable to assume that some or all of these individuals must have had previous infection with HSV. ${ }^{11}$

\section{Hybridisation of HSVI DNA to brain specimens}

(1) HSVI DNA sequences in brain cells Smears of brain samples (from the temporal lobe) obtained post-mortem were studied by in situ hybridisation

Table 1 Results of routine virological tests on patients under study

\begin{tabular}{|c|c|c|c|c|c|}
\hline Patient & $\begin{array}{l}\text { No of sera } \\
\text { tested }\end{array}$ & Minimum titre & Maximum titre & $\begin{array}{l}\text { No of specimens } \\
\text { tested }\end{array}$ & $\begin{array}{l}\text { Number yielding } \\
H S V\end{array}$ \\
\hline $\begin{array}{l}\mathrm{hbt} \\
\mathrm{mg} \\
\mathrm{ab} \\
\mathrm{wf} \\
\mathrm{mf} \\
\mathrm{pj} \\
\mathrm{mb} \\
\mathrm{ps}\end{array}$ & $\begin{array}{l}3 \\
6 \\
9 \\
5 \\
2 \\
5 \\
3 \\
1\end{array}$ & $\begin{array}{r}40 \\
80 \\
<10 \\
40 \\
160 \\
20 \\
<10 \\
<10\end{array}$ & $\begin{array}{r}80 \\
160 \\
80 \\
160 \\
>320 \\
80 \\
<10 \\
<10\end{array}$ & $\begin{array}{r}6 \\
12 \\
28 \\
22 \\
9 \\
21 \\
12 \\
1\end{array}$ & $\begin{array}{l}1^{*} \\
3^{*} \\
8^{*} \\
3^{*} \\
0 \\
0 \\
0 \\
0\end{array}$ \\
\hline
\end{tabular}

*For technical reasons, these strains could not be typed: it is probable that most, or all, were HSV1.

tDiagnosed as having HSV encephalitis. 

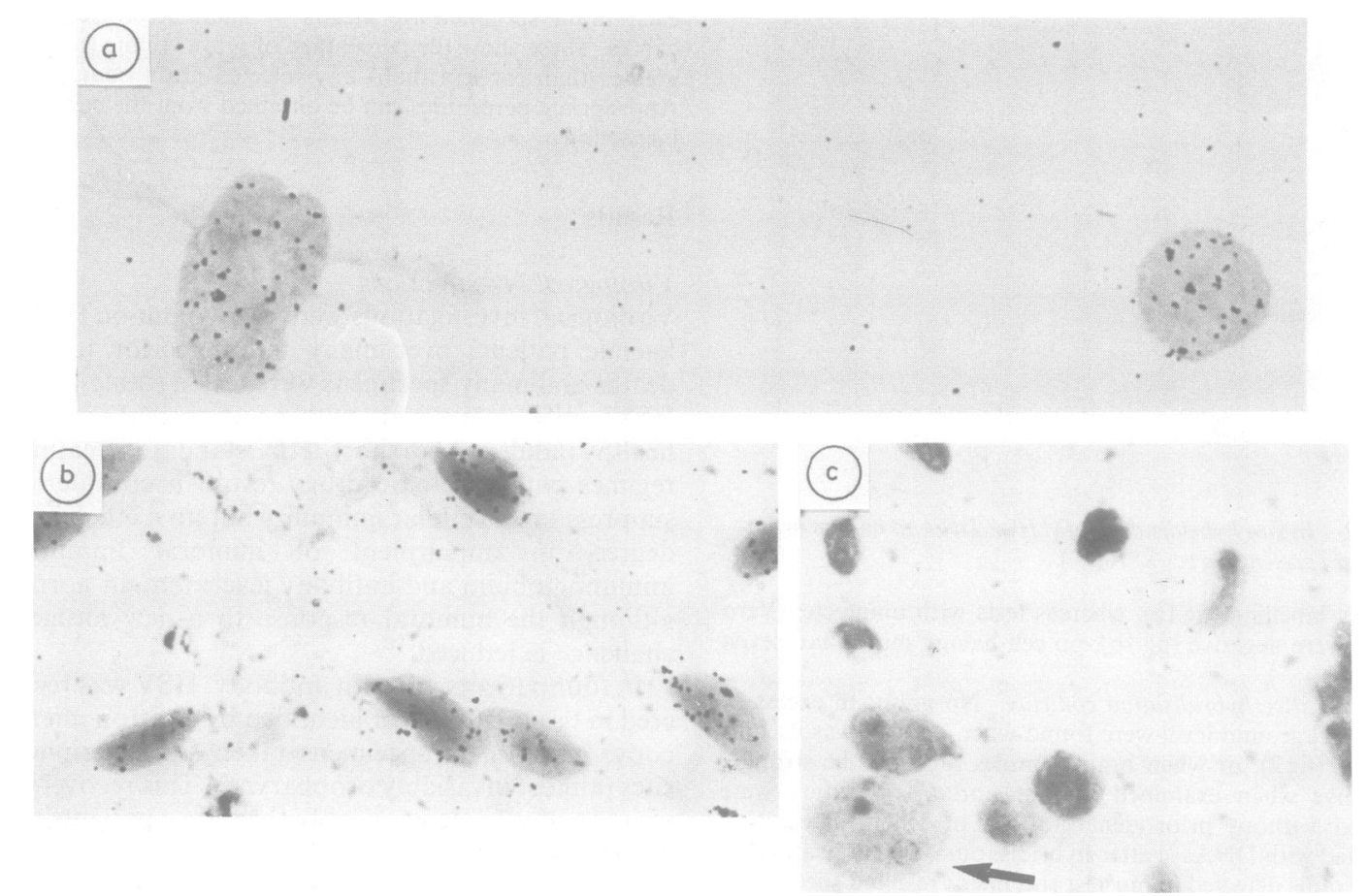

Fig 3 In situ hybridisation of $\left[{ }^{3} \mathrm{H}\right]-H S V I$ DNA to human brain smears. Small pieces of frozen tissue were smeared on to gelatine-coated slides, fixed in ethanol-acetic acid (3:1) for 20 minutes at $0^{\circ} \mathrm{C}$, air-dried and hybridised as described in Methods. (a) positive neuronal nuclei (patient $\mathrm{mg}$ ), (b) positive endothelial nuclei (patient $\mathrm{mg}$ ), (c) negative neuronal nucleus-arrow (patient pj). Scale bar 6.3 $\mu \mathrm{m}$.

with $\left[{ }^{3} \mathrm{H}\right]-\mathrm{HSV} 1$ probes. The majority of labelled cells were neurons but, in two cases ( $\mathrm{mg}$, hb), endothelial cells were also labelled. Figure $3 a-c$ shows positive neurons, positive endothelial cells and negative cells.

Examination of the cumulative frequency curves (fig 4) indicates differences in median grain counts but much more marked are the changes in the distribution of grain counts at the top two centiles. For this reason, we have rejected the usual significance tests which examine differences in medians: discrimination between positive and negative samples can best be achieved by simple examination of grain count distribution, the shape of the whole distribution being the prime indicator. Figure 4 thus shows a clear distinction between cases $\mathrm{hb}, \mathrm{mg}$ and $\mathrm{ab}$, in which many cells have very high grain counts and cases tw, gh and ts, in which few have values above background. In cases hb, mg and ab, at least $75 \%$ of the nuclei have 10 or more grains and at least $35 \%$ have 20 or more grains; these are defined at positive. In cases tw, gh and ts, $90 \%$ of the nuclei have 10 or fewer grains;

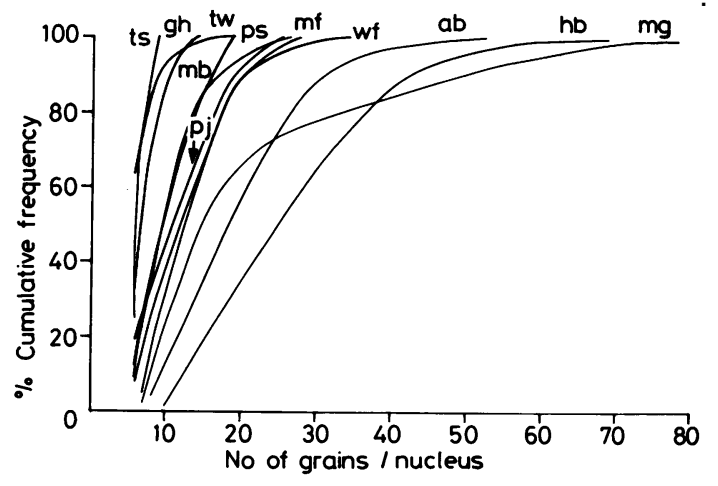

Fig 4 Percentage cumulative frequency of nuclei containing 6 grains or more, plotted against number of grains per nucleus. The cumulative frequency curves of grains in neuronal nuclei only are shown, except for patient ps where the cumulative frequency curve of grains in endothelial nuclei is shown as very few neurons were present. For convenience of display, experimental points are omitted but all are fitted smoothly by the above curves. 
Table 2 HSVI DNA sequences in brains of patients and controls

\begin{tabular}{|c|c|c|c|c|c|c|c|}
\hline \multirow[t]{2}{*}{ Group } & \multirow[t]{2}{*}{ Patient } & \multirow{2}{*}{$\begin{array}{l}\text { Immuno- } \\
\text { compromised }\end{array}$} & \multicolumn{2}{|l|}{ Percentage of cells } & \multirow{2}{*}{$\begin{array}{l}\text { In situ } \\
\text { hybridisation } \\
\text { summary }\end{array}$} & \multicolumn{2}{|c|}{$\begin{array}{l}\text { Virological evidence of past } \mathrm{HSV} \\
\text { infection }\end{array}$} \\
\hline & & & $\begin{array}{l}\text { with } 10 \text { or more } \\
\text { grains } \\
\%\end{array}$ & $\begin{array}{l}\text { with } 20 \text { or more } \\
\text { grains } \\
\%\end{array}$ & & $\begin{array}{l}\text { Positive } \\
\text { serology }\end{array}$ & $\begin{array}{l}\text { HSV } \\
\text { recovered }\end{array}$ \\
\hline $\begin{array}{l}\text { A } \\
" \\
" \\
" \\
" \\
" \\
\text { B } \\
\text { " }\end{array}$ & $\begin{array}{l}\mathrm{hb} \\
\mathrm{ab} \\
\mathrm{mg} \\
\mathrm{mf} \\
\mathrm{wf} \\
\mathrm{pj} \\
\mathrm{mb} \\
\mathrm{ps} \\
\mathrm{tw} \\
\mathrm{gh} \\
\mathrm{ts}\end{array}$ & $\begin{array}{l}\text { - (encephalitis) } \\
+ \\
+ \\
+^{*} \\
+^{*} \\
+ \\
+ \\
+ \\
- \\
- \\
-\end{array}$ & $\begin{array}{r}92 \\
85 \\
75 \\
68 \\
62 \\
55 \\
44 \\
41 \\
10 \\
10 \\
0\end{array}$ & $\begin{array}{r}63 \\
40 \\
35 \\
12 \\
14 \\
7 \\
0 \\
7 \\
0 \\
0 \\
0\end{array}$ & $\begin{array}{l}++ \\
++ \\
++ \\
+ \\
+ \\
? \\
- \\
- \\
-- \\
--\end{array}$ & $\begin{array}{l}+ \\
+ \\
+ \\
+ \\
+ \\
+ \\
- \\
- \\
\text { NKt } \\
\text { NKt } \\
\text { NKt }\end{array}$ & $\begin{array}{l}+ \\
+ \\
+ \\
- \\
+ \\
- \\
- \\
\text { NKt } \\
\text { NKt } \\
\text { NKt }\end{array}$ \\
\hline
\end{tabular}

*Including total body irradiation.

†Not known.

these are defined as negative.

As to the intermediate cases, wf and $\mathrm{mf}$ have about $65 \%$ of cells with 10 or more grains and about $13 \%$ with 20 or more grains; these can be classed as positive. In contrast, in mb and ps, almost $60 \%$ of cells have 10 grains of less and almost none have 20 grains or more and these can be classed as negative. Case pj remains uncertain.

Table 2 summarises these results.

(2) The relation of HSVI DNA sequences in brain to previous $H S V$ infection HSV1 DNA sequences were clearly detectable in brain tissue from the patient with HSV encephalitis (hb). They were also present in three patients (ab, mg, wf) with serological evidence of past HSV infection and with reactivation of virus in the oropharynx, and in one patient $(\mathrm{mf})$ with serological evidence of past infection alone.

HSV1 DNA sequences were not present in brain tissue from two patients with no virological evidence of past HSV infection (mb, ps). They were not present in brain tissue from the three patients (tw, gh, ts) with unknown histories of past HSV infection.

There was a statistically signiticant association between the presence of HSV antibodies and the presence of HSV1 DNA sequences in brain tissue $(p=$ 0.048 , Fisher's exact test). The relationship between the recovery of HSV from oropharyngeal swabs taken in life and the presence of HSVI DNA sequences in brain, although not statistically significant $(p=$ $0 \cdot 143$, Fisher's exact test), showed a suggestive trend, in view of the small numbers tested.

(3) The relation of HSVI DNA sequences to immunosuppression HSV1 DNA sequences were present in brain from four immunocompromised patients (ab, $\mathrm{mg}$, wf, $\mathrm{mf})$ and in one nonimmunocompromised patient (hb) with HSV encephalitis. They were not present in three nonimmunocompromised patients (tw, gh, ts) or in two patients with negative histories of past HSV infection (mb, ps).

When the patients with negative HSV histories and the patient with HSV encephalitis were excluded from analysis, there was a significant association between the presence of HSV1 DNA sequences in brain tissue and a history of immunosuppression $(p=0.029$, Fisher's exact test).

\section{Discussion}

We have asked the question "Does immunosuppression in man result in reactivation of latent HSV in brain tissue?" To answer this, we have produced data which, owing to the present and future use of prophylactic antivirals ${ }^{19}$ in patients such as we have studied, will not be obtainable in future.

Our study confirms and extends previous reports from this laboratory ${ }^{2}$ and elsewhere ${ }^{3}$ that latent HSV1 DNA sequences are present in human brain tissue in certain cases, and is the first in which clinical and virological observations of patients have been made during life. It indicates that reactivation of latent virus occurs in immunosuppression; this results in a sufficiently high level (that is, in effect, an amplification) of viral DNA in brain to be detectable by in situ hybridisation as well as in recovery of HSV1 in throat swabs due to passage of virus distally from the ganglia.

A novel observation in patients $\mathrm{mg}$ and $\mathrm{hb}$, where the concentration of hybridising sequences (shown by grain density) was particularly high, was that endothelial cells as well as neurons were labelled. Since latency is most unlikely to become established in nonneuronal cells, it may be that on reactivation of latent virus in neurons (for example following immunosuppression), adjacent non-neural cells become infected but at a level below that detectable by tissue cul- 
ture inoculation. In other specimens with somewhat lower grain counts, the concentration of reactivated virus may have been insufficient to infect adjacent cells.

A recent study by Taylor et al, ${ }_{2}^{20}$ substantiates our suggestion that immunosuppression leads effectively to "amplification" by reactivation of "pre-existing viral genome, thus increasing its detectability. In 83 brain samples from normal individuals and from patients with Huntington's chorea and schizophrenia, cytomegalovirus DNA was detected by dot-blot hybridisation in only one case, this being a normal individual who had previously been immunocompromised. ${ }^{20}$

It is most unlikely that our results are due to the presence of any sequences in cellular DNA which are homologous to viral DNA sequences and could therefore hybridise with probe, giving false positives. Jones (KW) et $^{21}$ detected sequences homologous to adenovirus 2 genome in human placental tissue but later $^{22}$ suggested that pre-existing sequences may have been amplified owing to the abnormal growth characteristics of this tissue. Similar arguments could apply to the findings of Peden et $\mathrm{al}^{23}$ who used human placenta and Puga et al $^{24}$ who used HeLa and human leukaemia cell lines and who, by Southern blot, detected homology between the repeated sequences (the joint regions and the ends) of HSV DNA and certain intermediate repetitive $(G+C)$ rich cell DNA sequences. However, the latter findings have been attributed by Jones (TR) and Hyman ${ }^{25}$ to artefactual hybridisation of G-rich probe (portions of the joint region comprise over $80 \%(\mathrm{G}+\mathrm{C})$ ) to $\mathrm{C}$-rich human DNA, on the basis of blocking experiments using added poly $(\mathrm{U}, \mathrm{G})$.

Even if such homologies do exist, a strong argument against our results reflecting this is that all cells of a similar type in all our samples would then show a few excess grains, and this is contrary to our findings. The absence of such hybrids here may be due to our use of highly stringent conditions and/or the presence of denatured calf thymus DNA, which contains $35 \%$ highly repetitive $(G+C)$-rich sequences and could thereby preclude artefactual binding or binding to homologies by the probe. Alternatively, although in situ hybridisation is a very sensitive method for detecting long sequences of DNA such as the HSV genome, it is insensitive to short sequences unless the latter are tandemly repeated. Thus, any homologous cellular sequences which are relatively short might not be revealed here even if present in large numbers.

As to the nature of the latent viral DNA, Rock and Fraser ${ }^{5}$ have shown by Southern blot hybridisation that most or all of the HSV genome is present in latently infected mouse CNS tissue, possibly in a cir- cular or concatenated form. However, a recent study by Puga $\mathrm{et} \mathrm{l}^{26}$ indicates that part of the HSV genome is rearranged during latency. This would not affect its detectability by HSV DNA probe, provided the size of the latter were sufficiently small, as it is in our case (approx 100 bases).

Our detection of HSV1 genome in the brains of immunosuppressed patients parallels the results of Kastrukoff et $\mathbf{l}^{10}$ who have shown in latently infected mice, by co-cultivation, that massive immunosuppression results in a transient infection of the CNS. It should be noted though that studies of animal models may not relate in all aspects with human disease. ${ }^{27}$

We conclude that immunosuppression in man, whether iatrogenic (as in our patients) or from natural causes (for example infection ${ }^{2829}$ or aging $^{30}$ ), may be associated with reactivation of HSV in the temporal lobes of the brain as well as peripherally. Acute HSV encephalitis is commonly localised to these lobes and causes serious neuropsychiatric illness. We therefore speculate that minor degrees of virus reactivation, such as we have detected here, could cause less gross but still significant disease, particularly if reactivation occur repeatedly.

We are greatly indebted to Professor HC MacGregorn for help with in situ hybridisation techniques, Dr $F_{\mathrm{D}}$ Reid for advice on recognition of nerve cell types, DP A Curry for electron microscopy, Dr H Anderson and Professor BE Tomlinson for brain samples and to Mrs R Ward and Mrs DE Monaghan for invaluable help.

This work was supported by the Medical Research Council and the Mental Health Foundation. A preliminary report of this work is in press. (Trans Biochem Soc.).

\section{References}

${ }^{1}$ Goodpasture EW. Herpetic infection with especial reference to involvement of nervous system. Medicine 1929;8:223-43.

${ }^{2}$ Sequiera LW, Carrasco LH, Curry A, Jennings LC, Lord MA, Sutton RNP. Detection of herpes simplex viral genome in brain tissue. Lancet 1979;ii:609-12.

${ }^{3}$ Fraser NW, Lawrence WC, Wroblewska Z, Gilden DH, Koprowski H. Herpes simplex type 1 DNA in human brain tissues. Proc Nat Acid Sci USA 1981;78:6461-5.

${ }^{4}$ Cabrera CV, Wohlenberg C, Openshaw H, Rey-Mendez M, Puga A, Notkins AL. Herpes simplex virus DNA sequences in the CNS of latently infected mice. Nature 1980;288:288-90.

${ }^{5}$ Rock DL, Fraser NW. Detection of HSV-1 genome in central nervous system of latently infected mice. Nature 1983;302:523-25. 
${ }^{6}$ Oldstone MBA, Sinha YN, Blount $\mathrm{P}$, et al. Virus-induced alterations in homeostasis: alterations in differentiated functions of infected cells in vivo. Science 1982;218:1125-7.

${ }^{7}$ Puga A, Rosenthal JD, Openshaw H, Notkins AL. Homology between murine and human cellular DNA sequences and the terminal repetition of the S component of herpes simplex virus type 1 DNA. Virology 1978;89:102-11.

${ }^{8}$ Tenser RB, Dawson M, Ressel SJ, Dunstan ME. Detection of herpes simplex virus mRNA in latently infected trigeminal ganglion neurons by in situ hybridisation. Ann Neurol 1981;11:285-91.

${ }^{9}$ Galloway DA, Fenoglio C, Schevchuk M, McDougall JK. Detection of herpes simplex RNA in human sensory ganglia. Virology 1979;95:265-8.

${ }^{10}$ Kastrukoff L, Long C, Doherty PC, Wroblewska Z, Koprowski H. Isolation of virus from brain after immunosuppression of mice with latent herpes simplex. Nature 1981;291:432-3.

${ }^{11}$ Gerdes JG, Smith DS. Recurrent phenotypes and establishment of latency following rabbit keratitis produced by multiple herpes simplex virus strains. J Gen Virol 1983;64:2441-54.

${ }^{12}$ Bradstreet CMP, Taylor CED. Technique of complement-fixation test applicable to the diagnosis of virus diseases. Mon Bull Minist Hlth Lab Serv 1962;21:96-9.

${ }^{13}$ Ben-Porat T, Demarchi JM, Kaplan AS. Characterisation of defective interfering viral particles present in a preparation of pseudorabies virions. Virology 1974;61:29-37.

${ }^{14}$ Rigby PWJ, Dieckmann M, Rhodes C, Berg P. Labelling deoxyribonucleic acid to high specific activity in vitro by nick translation with DNA polymerase I. J Molec Biol 1977;113:237-51.

${ }^{15}$ Saldanha J, Gannicliffe A, Itzhaki RF. An improved method for preparing DNA from human brain. $\mathrm{J} \mathrm{Neu}$ rosci Meth 1984;11:275-9.

${ }^{16}$ MacGregor HC, Varley JM. Working With Animal Chromosomes. Chichester: J Wiley \& Sons, 1983:213-26.

${ }^{17}$ Brandsma J, Miller G. Nucleic acid hybridisation: rapid quantitative screening test of lymphoid cells for Epstein-Barr viral DNA. Proc Nat Acad Sci 1980;77:6851-5.

${ }^{18}$ Dale DC. Defects in Host Defence Mechanisms in Compromised Patients, In: Rubin RH, Young LS, eds. Clinical Approach to Infection in the Compromised Host. New York and London: Plenum, 1981:35-74.
${ }^{19}$ Anderson H, Scarffe JH, Sutton RNP, Hickmott E, Brigden $\mathrm{D}$, Burke C. Oral acyclovir prophylaxis against herpes simplex virus in non-Hodgkin lymphoma and acute lymphoblastic leukaemia patients receiving remission induction chemotherapy. A randomised double blind, placebo controlled trial. Br J Cancer 1984;50:45-49.

${ }^{20}$ Taylor GR, Crow TJ, Higgins T, Reynolds G. Search for cytomegalovirus in postmortem brain tissue from patients with Huntington's Chorea and other psychiatric disease by molecular hybridization using cloned DNA. J Neuropathol Exp Neurol 1985;44;2:176-84.

${ }^{21}$ Jones KW, Kinross J, Maitland NJ, Norval M. Normal human tissues containing RNA and antigens related to infectious adenovirus type 2. Nature 1979;277:274-9.

${ }^{22}$ Maitland NJ, Kinross JH, Busuttil A, Ludgate SM, Smart GE, Jones KW. The detection of DNA tumour virusspecific RNA sequences in abnormal human cervical biopsies by in situ hybridisation. J Gen Virol 1981;55:123-37.

${ }^{23}$ Peden K, Mounts P, Hayward GS. Homology between mammalian cell DNA sequences and human herpes virus genomes detected by a hybridisation procedure with high-complexity probe. Cell 1982;31:71-80.

${ }^{24}$ Puga A, Cantin EM, Notkins AL. Herpes simplex virus DNA and mRNA sequences in acutely and chronically infected trigeminal ganglia of mice. Cell 1982;31:81-7.

${ }^{25}$ Jones TR, Hyman RW. Specious hybridization between Herpes Simplex Virus DNA and Human Cellular DNA. Virology 1983;131:555-60.

${ }^{26}$ Puga A, Cantin EM, Wohlenberg C, Openshaw H, Notkins AL. Different sizes of restriction endonuclease fragments from the terminal repetitions of the herpes simplex virus type 1 genome latent in trigeminal ganglia of mice. J Gen Virol 1984;65:437-44.

${ }^{27}$ Wildy P, Field HJ, Nash AA. Classical herpes latency revisited. In: Mahy BWJ, Minson AC, Darby GK, eds. Virus Persistence. SGM Symposium 1982;33:133-67.

${ }^{28}$ Haider S, De Coutinho M de L, Emond RTD, Sutton RNP. Tuberculin anergy and infectious mononucleosis. Lancet 1973;ii:74.

${ }^{29}$ Bowne TJ, Wedgwood RJ, Ochs HD, Henle W. Transient immunodeficiency during asymptomatic Epstein-Barr virus infection. Pediatrics 1983;71:964-7.

${ }^{30}$ Wedelein C, Bjorkholm M, Holm G, Ogenstad S, Mellstedt $\mathrm{H}$. Blood T-lymphocyte functions in healthy adults in relation to age. Scand $J$ Haematol 1982;28:245-53. 